\title{
The Environmental Perspectives of Tunisian Accounting system: a Theoretical Study and Recommendations for Improvement
}

\author{
Amara Tijani \\ ISAE, University of Gafsa, Tunisia \\ Correspondence should be addressed to: Amara Tijani; tijani_amara@yahoo.fr \\ Received date: 29 November 2013; Accepted date: 30 July 2014; Published date: 5 March 2015 \\ Academic Editor: Artene Alin Emanuel \\ Copyright (C) 2015. Amara Tijani. Distributed under Creative Commons CC-BY 4.0
}

\begin{abstract}
The integration of the environmental dimension in the business's life does not mean taking into account economic, financial and legal terms but also in the accounts. According to this point of view, the recognized of environmental aspects is considered as an important factor in the evaluation of the performance of the business tool. It is recently as Mikol (2005) indicates that the accounting has been recognizing as one of the instruments for the company to achieve environmental excellence. Today, we think over not manage what you cannot measure. This recognition has forced business leaders to think seriously about the impact of activities on the environment of the company. In such context, the protection of the environment is as important as financial performance.The present work is based on an analytical and critical study of the current accounting system. Thus, we present first all the issues related to the environment and the importance of disclosure of environmental information in financial reports. Then, we analyze the financial accounting system and its limits to the development of environmental accounting. Finally, we will present some solutions deemed necessary for the recognition of environmental issues in corporate financial reporting.
\end{abstract}

Keywords: Environmental protection, environmental policy, environmental accounting, stakeholders.

\section{Introduction}

Integrate the environment into the daily life of the company does not assume its inclusion only in the economic, financial and legal fields, but also in the accounts fields. From this perspective, the recognition of environmental aspects is a tool for evaluating the performance of the company.
Traditionally, the accounting aspects of business operations are exclusively accounting professionals. These aspects are managing to meet the demand for shareholder information and requirements in various jurisdictions. It is only very recently as indicated by Mikol (2005), that accounting is recognized as an instrument enabling the company to achieve environmental excellence. Today, it is very 
urgent to manage what is not measurable. This recognition forces business leaders to think seriously about the impacts of activities on the environment of the company. In this environment, the protection of the ecosystem is as important as financial performance. This ecosystem is treated as if it were a traditional asset. All members of the community and those that will follow share ownership of the asset. He is responsible for the production of many resources we consume. Gray (1990) uses the term "natural capital" to describe the economic ecosystem. On this basis, there will be a profit accounting since it will only be assuring when the activities of businesses were conducted in order to preserve this heritage. Moroncini (1998) argues that when it comes to an asset whose ownership is shared by the whole community, it is the duty of everyone to ensure its protection.

The environmental protection and the safeguard of the heritage are only possible when companies fulfill their social responsibilities. This is possible also that when establishing evaluation techniques to identify the impacts of activities on the environment and account. The research methodology is based on three phases. The first is a descriptive phase in which we describe the contents of the current accounting system and more particularly that have a relation with the environmental disclosure. The second phase is detecting the limits that present the current accounting system for the development of a model disclosure. Finally, the third phase focuses on proposals for improvement that can be adopted to address current shortcomings. We first present the issues related to the environment and the importance of disclosure of environmental information in financial reports. Next, we analyze the financial accounting system and that this limits the development of environmental accounting. We will finish this paper by presenting some solutions deemed necessary for the recognition of environmental issues in the corporate financial reporting.

\section{Environmental information: Increased importance to stakeholders}

With the development of human activity, the environment has changed. These changes directly threaten human beings himself because of the adverse effects that accompany the development of polluting industries. Stakeholders who interact directly or indirectly with these companies are now refusing to neglect environmental problems. Stakeholders are going further by saying that all companies must adopt policies and strategies of environmental protection.

Gradually, companies under the strong pressure of the community became aware of the risks associated with the developments of their activities. Their concerns are directing towards minimizing the negative effects on the environment. Pierre Andre (1999) confirms that the majority of them consider that respect for the environment is a competitive factor enabling the company to control pressures regulatory, economic, fiscal and social pressures. Within this framework, Beauchamp (1993) emphasizes that the integration of the environment is challenging for two reasons. On the one hand, the integration of the environment is considered a competitive factor. Environmental control costs are therefore a key to business continuity. Moreover, policy makers and the community, although difficult to quantify, cannot neglect the impact of environmental costs. The inclusion of these costs is therefore a requirement for any strategy of economic and social development.

This orientation is indeed a step towards integrating the concept of sustainable development into business strategies which, among these goals, are preserving resources for future generations and improving the social and environmental performance of companies. According to Delphine (2008), the responsible company is one that reflects the consequences of its actions on oneself and one's surroundings. The corporate responsibility becomes an aspect to "achieve commercial success by honoring ethical values, respect for 
individuals, communities and the environment. » (Rubinstein M, 2006, p 6). At the Johannesburg Summit in 2002, companies undertake to implement a true "business ethics", is intervene in society as a corporate citizen to influence policy choices (Capron and Quairel-Lanoizelée, 2007).

The corporate citizenship reflects its integration into social life. Its scope is not only economic but also social, cultural and political. This means according Moussé (1997), the company does not take into account only the negative consequences of its activities on society but also minimize and disclose its efforts in environmental protection in the form of information published in financial reports. Thus, the company accepts its social responsibility when it meets all legal and regulatory obligations. The company according to Mathews (1993) undertakes voluntary actions. Activities may include three distinct components:

- They may derive from the unintended consequences related business activity; - They may concern the quality of life within and outside the company; - They can be in the form of information on the situation of the environment in which enterprises operate. Companies, according to Carroll (1979), are vital centers of decision and power. Their actions affect the lives of partners in many areas. Carroll (1979) sees the concept of Corporate Social Responsibility is the set of commitments vis-à-vis society. In this context, the SCR defines three kinds of economic commitments, legal, ethical and human. With the concept of corporate social responsibility presented by Carroll, some researchers (Jonas, 1990), consider him the founder of theoretical approaches. The concept goes well, a reflection on how to share a reflection on the need to refer to ethics. The Corporate Social Responsibility covers according to Mohamed et al (2009) the social and environmental issues. For Allouche (2004) this concept gives rise to a mature view of the term responsibility that integrates traditional constraints of environmental protection and respect for rules of balance of civil society. Social responsibility is the subject of increased attention from many international organizations of many kinds.

Capron et al (2004) argue that the notion of corporate social responsibility is based on the scrutiny of stakeholders. The majority of the concepts of corporate social responsibility mean the voluntary integration of social and environmental priorities of their business activities. A socially responsible company means not only satisfying the applicable legal requirements, but also investing more in human capital, environment and relationships with stakeholders (European Commission, 2001). The nature of the relationship between business and stakeholders will effectively determine the expectations of the latter company. These expectations can be and sometimes conflicting, depending on the needs of each individual having a direct or indirect relationship with the company. The specific expectations of each stakeholder could be the reliability and transparency of information, the environmental and health risk related to products and activities, the social and environmental policy, the respect for community environmental and social regulation and the legal responsibility.

We note that the majority of individuals constituting the stakeholders interested in the environmental factor. Thus, compliance with environmental regulations and the reliability and transparency of information activities are factors present in all stakeholder expectations. This explains, in fact, the awareness of stakeholders on the role business can play to protect society. According to Turner et al (2003), the nature of expectations contributes to the optimal allocation of resources and protecting the interests of future generations.

Issues related to the environment have become increasingly important in recent years. This information covers according to Solomon et al (2001) the following: the share of the company to preserve the environment, the policy towards the consumer, the impact of company activities 
on the national and global economy, the action to save energy and action to improve products or services rendered. Their shares, several countries in the world have contributed to environmental protection and, by requiring strict regulations regarding environmental France, as indicated by Capron et al (2000) and convince one of the first countries of the importance of an ecological measure system within the company. In this context, Cormier et al (2001) argue that France provides a framework for the standardization of environmental binding. Although, French regulations are relatively binding, 12 of 25 do not companies disclose any environmental information.

German companies go further according to Cormier et al (2001) by recruiting listeners devoted to the control of environmental information. On its part, Britain was the first country to issue rules addressing several environmental performances such as the Eco Management and Auditing Scheme (CICA, 1994). The results of the study by Adams et al (2000) confirm that the percentage of UK companies protection that publish environmental information has increased from $10 \%$ in 1986 to $60 \%$ in 1989 and the average length of pages that contain ecological information have increased from $0.34 \mathrm{~cm}$ in 1985 to $1.62 \mathrm{~cm}$ in 1995.

However, it is important to note that U.S. environmental regulations are one of the most demanding and more rigid in the world. In this context, Moneva et al (2000) argue that the level of disclosure of environmental information of U.S. firms is higher than the level of disclosure of environmental French and German companies. This is justified by Bartolommeo (2000) by spending U.S. companies dedicated to the restoration of damaged sites that are greater than expenses incurred by European companies for the same purpose. According to Guthrie et al (1990), the level of the disclosure of environmental information of a company depends on the social conscience of the country in which it operates. Fortin (1995) adds that the legal contexts, socio-political and financial help the mandatory to disclosure the environmental information.

\section{The limits of financial accounting system}

The financial accounting system imposes many restrictions on the development of an environmental accounting. The rules for finding an accounting item in the financial statements are probably the source of the most important ones. It is through their standard of reasonable estimate that the recognition rules allow several companies to escape from their environmental responsibilities. According to Skinner (1987), the decision on the possibility of making a reasonable estimate of an amount is subjective. The judgment may be distorting especially if one wishes to omit liabilities that might tarnish the image of the financial situation.

It might even happen that a bill could threaten unrecognized environmental sustainability of the organization. According to the paragraph 13 of the Accounting standard $\mathrm{N}^{\circ} 5$, the Tunisian accounting system requests that the tangible asset that meets the criteria for classification as an asset, should initially be measured at its acquisition cost. It adds that the financial statements are prepared on the historical cost basis. Operations and the facts are thus recorded at the amount of cash paid or received or the fair value attributed to them when they responded. The support given to the historical cost is due to its reliability, verifiability and objectivity.

Unfortunately, the measurement of most of environmental costs depends on events and invoices that are yet to come. The finding of these costs based on history cannot be done. As a result, when we want to determine the environmental cost, we use an estimate that falls within the scope of subjectivity.

We believe that given the potential impact that these bills contain environmental unrecognizing on the financial position of the company, the loophole should be closing. We believe also that having 
subjective information is better than no information at all. Moreover, we know there are many ways to estimate or verify the validity of the assumptions that justify the estimate. Finally, the researchers note that the current accounting system leaves much choice to the direction when time comes to select the information to disclose in annual reports.

When we demand according to the accounting system all relevant information to readers, we do not leave the choice to the management to present or not the information. While, this information will not occasionally strategic implications on the organization, it is nonetheless true that they are of interest to most readers.

This is not to decide the direction of desirable information for the reader even though it may suggest the absence of materiality or the cost-benefit relationship to justify a refusal. Especially since the accounting system explicitly recognizes that benefits can come back to the parties that do not bear the costs. A better investment decision or financing is an example of advantage to consider.

Without notes that appear in the financial statements, the current accounting system does not seem able to meet the information needs of environmental decision-makers today. Therefore, Hawkshaw (1991) confirms the theory few firms that describe how they address the environmental costs. Could it be that these costs are minimal or is it we use the flexibility provided by the current accounting system to avoid this information? Could it be otherwise if the system was designed in a context of sustainable economic development? Simply because the financial accounting system is based on the concept of a traditional market economy, it cannot serve the interests of a sustainable economy without accepting significant compromises. Basing his choice of disclosures about the imperatives of stewardship responsibility on the owners, the current system greatly reduces the potential for disclosure and excluded a priori considerations of social order. This is why Rubinstein (1991) said that:
- define the asset, as a benefit that the company could obtain in the future because of past transactions or events is narrow. We excluded outright any form of future economic benefit that could benefit a third party outside the organization;

- define the liability as an obligation of the company in the future sacrifice of economic resources. We excluded outright any form of economic sacrifice a third party unconnected with the company should have to endure because of the activities of this organization.

The financial accounting system only cares about financial interests and those of a class of corporations or donors and, more specifically, the shareholders. The ultimate objective of the present system is to provide information against which to measure the enrichment of shareholders and lenders as well as the risk posed by this enrichment of the quest. The result is that, the overestimate of the performance of a company that does not care about the environment and to underestimating the performance of a company that respects the environment. Because the system does in no way reflect the value of the use of the collective heritage used by the company, unscrupulous managers maximize their profits by taking advantage of the natural heritage. Those who seek to restore heritage will merge their results. From there to argue that, the current accounting system indirectly encourages the company to the excessive consumption of natural heritage.

Even if the will to serve the interests of others are invisible and participate in the protection of natural heritage seems to be happening in some companies, we are still faced with very special characteristics of environmental obligations. According to Rubinstein (1991), the characteristics of environmental obligations are:

- Their long settlement period;

- Uncertainties included;

- The complexity estimates they require; 
- The absence of contracts that set out clearly and explicitly the rights, benefits and obligations of the stakeholders.

It is based on those characteristics that, according to Rubinstein (1991), the concepts of private ownership and stewardship responsibility to shareholders can be the basis for accounting for environmental obligations.

The measure also poses its cash difficulties. Because the cash value of the collective heritage is difficult or impossible to establish. It is easy to imagine that establishing the cash value of the deterioration of this heritage and its impacts on the community will present à serious challenges. This does not mean that no recovery is possible. We simply wanted to express the additional difficulties facing us in the traditional approach to the measure applied by the current accounting system.

We also know that the accounting data of these companies do provide indications on the evolution of their financial resources because they are the only measurable in cash. This could lead to higher profits present, despite the increase in externalities. In this context, Peskin (1991) emphasizes "pollution, congestion, and depletion of natural resources are often unfortunate side effects of economic growth." In addition, conventional economic indicators reflect poorly sharpen efforts to defend against environmental insult.

\section{Prospects for Improved Tunisian financial accounting system}

Defining the objectives of financial statements that present the current accounting system clearly shows that these states are sticking to the production of information on the economic performance of the company. Any other form of performance measure takes us out of the current conceptual framework. Moreover, we restrict the range of users served investors and creditors.
Then we can understand according to Oxibar (2003), why many argue that the current accounting standards discourage the implementation of measures to protect the environment. It also assumes that extending the meaning of the word "performance" to other realities seems to be than simple financial flows.

Beyond its deterrent effect on the development of environmental accounting, the current formula does, for all practical purposes, no explicit requirement in respect of information of environmental nature.

It is only implicit in that certain elements of the current accounting system could lead us to include anything other than traditional financial reporting. The following considerations on the relative importance found in paragraph 18 of the conceptual framework: "Further information is useful for economic decision making. This information reflects the need to refine or supplement the range of information for users, and may include:

- The financial prospects of the company's activities,

- Activities related to human resources management,

- The impact of company activities on the ecological environment and the actions that it has committed to ensure the preservation and protection of the environment

Unfortunately, finding an item in the financial statements is recommended only when the estimate is almost devoid of uncertainty. Invoking the standard that many are beyond the publication of environmental information deemed harmful to the company's image. In response, Fortin (1995) propose that we make a point of maximum use of estimates when you cannot establish the exact position of an element to describe. He also suggested that this duty becomes absolute requirement when the item being described is a liability. 
Boritz (1990) has addressed this issue mainly with respect to key potential losses from litigation. According to his analysis, one of the main problems related to the publication of information on litigation stems from the fear that recognition of these and, even worse, the estimated losses that will be associated indicates the opposing party of the strategy the organization has adopted or intends to adopt.

This reflects the needs of decision makers. They want the information needed to predict the future of their investments. The criterion of reasonable estimate can be "reasonable" but not the ability of the reasonable estimate that determines the existence and value of the element in question. Accordingly, it should always reveal the existence of a liability and provide an indication of its financial impact. It is probably for this reason that the study group of the CICA (1993b) recommends that publishes the range of potential financial implications of environmental losses when it is not possible to estimate the exact amount.

Contingencies, in turn, are future events that by their nature, involve uncertainties. A rational decision maker is interested in the probability of materialisation of the possibility. Since financial accounting is used to streamline the process of decisionmaking, we can say that information on the probability of occurrence of the event and the impact of this event is also useful. In the current accounting system, the information provided on contingencies in financial statements will only be the extended of their negative financial impact. Sometimes along the information not be disclosed. We claim for our part, that all contingencies should be disclosing and that disclosure should be accompanied by its probability of realization. We also offer a practical framework for accounting for negative and positive externalities.

\section{Treatment of specific environmental costs}

According to paragraph 18 of the conceptual framework, firms must provide other information found in financial statements. This information is useful to know the impact of company activities on the ecological environment and the actions that it has committed to ensure the preservation and environmental protection.

The Paragraph 12 of the fifth accounting standard states that "The acquisition of real support such as training materials, safety, and environmental protection [...] may be necessary for the company to reap the benefits economic future of its other assets. When this is the case, such acquisitions of property, are entitled to be recorded as assets [...] However, these assets recognize only to the extent of the net book value. The related assets are no greater than the recoverable amount of the asset and its related assets. For example, a garment washed fabric may have to install a water treatment factory to comply with environmental obligations on the manufacture of such products. Such a station is recorded as an asset [...] The current accounting system deals with "contingencies". He recommends informing users that any uncertain situation could result in a gain or loss for the company. Thus, according to O'Donovan (2002), when a company faces a loss because its activities have caused environmental damage, financial statements must disclose the existence and quantify the consequences if it is reasonably practicable. Thus, "the financial statements must provide information on economic resources, the company controls, as well as the obligations and effects of transactions, events and circumstances may change its resources and obligations" (para 4 of the AS 14)

The accounting standard on expenditure on research and development deals with "costs of research and development" because many environmental activities presuppose major investment in scientific research. It is thus possible that the provisions of this standard also contribute to the treatment of environmental realities in the financial statements. 
In this sense, the research report of the CICA (1993) entitled Environmental Costs and Liabilities: Accounting and Financial Reporting, seeks to demonstrate that we can treat environmental costs recognized in the current year, future environmental costs as assets values resulting from environmental factors. It offers the disclosures in the financial statements on the environmental loads and suggests ways to use it to communicate environmental information.

We can consider four ways to deal with environmental costs: recognition as a change in accounting estimate, their allocation to one or to prior years, having been charging to the current year or an imputation or future years or as deferred charges as assets.

\section{Recognition as accounting change}

It is possible that environmental costs recognized in the current year call into question an estimate made in a prior year based on information available at that time. This could be the case of estimating an environmental liability, for example. (Rogers, 2005) In a similar situation, it will be calling for a change in accounting estimate.

We recommend instead the attribution of the effects of changes in the current fiscal year or its distribution over the current year and future years as the results of future periods are affected by the amendment. This recommendation reads "The effect of a change in accounting estimate should be recorded in the period in which the change occurs, if it only affects the results of this exercise, in the execution in which the changes take place and in the years following the results of which are affected by this amendment. "

According to paragraph 25 of the Accounting Standard on Accounting Changes " a change in an accounting estimate may affect the current year [...] In both cases, the impact of the change relating to the current year is recognized as income or expense in the current year. The impact, if any, on future periods is recognized in subsequent periods.

\section{Allocation over several financial accounting}

It is possible that environmental costs recognized in the current year are linked to environmental damage that occurred during one or more prior periods. Logic suggests that this cost is attributed to this or the previous years. However, the use of this solution requires that these costs must:

- be connected directly to the operation of a given past year;

- not be attributed to economic factors occurred since the end of the year in question;

- caused mainly by the will and actions of third parties (ie people who are not owners or shareholders, or members of management);

- not have been capable of reasonable estimation prior to the materialization of the acts, from which they derive.

Often the damage had been over several years and that only a portion of it can be linked directly to a given fiscal year (CICA, 1993). In addition, the damage will be annoyed by the vagueness of the concept of economic factor.

According to Skinner (1987), an economic factor is a fact or a transaction that occurs in the course of business of the company or changes in economic conditions affecting the financial position thereof. By this definition, costs incurred to comply with a law enacted during the current year are attributable to economic factors occurring after the close of previous years. Therefore, they cannot be attributed to these exercises even if they are relating to damage incurred in these exercises.

The last two restrictions also pose problems of interpretation. Management of the company incurs costs of rehabilitation because of external pressures. However, no bonds it is making no bonds in this direction by a regulatory agency. If this is the case, should we consider that these costs do not meet the third condition and load them to the current year? Did market pressures will consider the result of acts of 
third parties and we can straighten prior year results?

\section{Allocation to the current year}

Environmental costs directly or indirectly related to the benefits obtained in the current financial year should be automatically allocated to the year. They must also be attributed to the current year costs that are not sufficiently linked to future benefits to justify their capitalization and deferral. Gray (2002) confirm that this is the case, for example, for donations in programs related to the environment, environmental costs incurred after the acquisition or construction or development of an asset. It is the same, the costs related to prior years' activities or benefits are received during these exercises and cannot be treated as adjustments to prior years affected. For example, the costs of cleaning up a derelict site initiated by management.

We had the same rules applied when it comes to dealing with costs, which no benefit can be associated, such as fines for exceptions to environmental laws and regulations.

\section{Accounting as Assets}

In general, costs that are related to future benefits must be capitalized. While, the current accounting system does not contain specific standards to address directly the capitalization of environmental costs including several components that apply to the capitalization of environmental costs. The standard for capital may apply to certain environmental costs.

Thus, Dye (1985) confirms that it would be detaining for the costs of acquisition, construction or development of assets used for environmental protection, mitigation of contamination, repair damage environmental or resource conservation. The treatment of costs incurred after the acquisition, construction or development of assets must comply with the provisions of paragraph 12 of the NC5. According to the text of this paragraph, capitalizes costs that increase the service potential of the asset.
The provisions of Accounting Standard No. 20 that deals with development costs may apply to development costs incurred in the environmental field. Paragraph 13 of the standard specifies requirements to enable the deferral of development costs. We read this paragraph: "The allocation to the various exercises expenditure on research and development is carried out based on the relationship between these costs and benefits expected by the company of such research and development. When it is probable that this expenditure will result in future benefits and whether they can be reliably measured, they are qualified to be capitalized»

\section{The likely expenditure: proposals for treatment}

This research presents, in outline, the rules of accounting for future environmental burdens. It is particularly interested in those that are planned or likely. Two kinds of treatment are proposing: the recognition of a liability and the constitution of a provision for future losses or reference information in the notes.

\section{Recognition as a liability}

If the obligation to initiate the environmental loads resulting from future environmental damage is already caused, then it meets the definition of a liability. In this context, Shaltegger et al (2000) suggest that the treatment of environmental liabilities is, therefore, the application of recognition criteria. These criteria are:

- There is an appropriate basis of measurement for the item in question and it is possible to estimate the amount;

- For items involving obtaining or giving up future economic benefits, it is likely that such benefits will be obtained or abandoned.

Sometimes an item that meets the definition of a component is not found in the financial statements because it is unlikely that future economic benefits are achieved or abandoned because of the 
impossibility of making a reasonable estimate of the amount involved. It may be appropriate to provide in the notes, information about items that do not meet the recognition criteria.

Accordingly, if the amount of environmental liability can be reasonably estimated, it must be show in the financial statements. Moreover, in the case of future removal costs of a capital asset and site restoration can be determined at the cost of a reasonable effort Thus, they a provision must be made in through charges to the results of a systematic and rational manner.

\section{Findings of a provision}

Some environmental costs according to Dye (1985) are related to expect future operations and future facts. In case it does not provide benefit to these environmental burdens, we must be guided by the recommended treatments for other categories of future losses. Generally, the generally accounting principle requires the recognition of a provision for future losses against anticipated loads, which are not expecting to derive any advantage. This general principle should be applied to environmental charges provided that it will lead to future loss.

\section{Creation of specific environmental accounts}

Creating accounts externalities, negative externalities and net externalities raises the issue of the use value, that is to say, the social utility, and the exchange value or economic benefit. The economic utility account "externalities" can be characterized in this case of public goods. Indeed, a public good is an indivisible good whose individual consumption does not alter the collective use. Therefore, the market value of such a concept offered to all stakeholders of the company would be the credit obtained from all those involved in achieving the purpose. To be easily adopted, the accounts should be tax neutral. The positive account externalities would be assigned in seventh class products demonstrated that the company or the organization would have a productive capital of trust vis-à-vis its partners. Negative externalities are taken into account in sixth class loads and are designed to reduce the confidence that others may allow the target company. At the end of the year, accounts positive and negative externalities would be transferring to account externalities net. This would net increase or decrease the net income of account externalities. In the event of pollution or nuisance caused by the company, the amount would be included according to Gray (2002) in sixth Class "negative externality". The account "environmental liabilities", would offset the cost of the nuisance caused by the company and appeared in the balance sheet as a reminder that the company has a societal debt, as it has not repaired the damage.

\section{Conclusion}

Information on environmental aspects must be published as well as they affect the performance or financial condition of the undertaking, which draws up accounts. Based on the content provisions of the annual report and consolidated annual report of companies, where environmental issues can affect performance, financial statements of the company or its development, the management report should include a description of problems, and the company (ACCA, 2004) makes responses to them. It should present a fair review of the evolution of business and position the company to the extent that environmental issues may affect them directly. For this purpose, it is recommended to provide the following information:

a) Policies and programs adopted by the company regarding environmental protection, particularly in terms of pollution prevention. Users of annual reports must be able to determine the extent to which environmental protection is an integral part of political and business activities. Information provided may include, where appropriate, a reference to the adoption of a system of 
environmental protection, and the obligation to comply with a given set of associated standards or certifications;

b) The improvements in key areas of environmental protection: This information is particularly useful if detailed in an objective and transparent manner, the company's performance against a target figure (eg, emissions of the five previous years) and reasons for significant differences may have arisen;

c) the degree of implementation of measures of environmental protection, that have been taken or are being introduced to comply with existing legislation or to change in future, already agreed, legal obligations;

d) Where appropriate and relevant given the nature and scale of the activity of the company and the environmental problems associated with this activity, information on the environmental performance of the company in particular, of energy, materials and water, emissions and waste disposal

This information could usefully be provided as indicators of quantitative eco-efficiency, where relevant, detailed by type of activity. For Yusoff and Lehmann (2005), it is particularly desirable to provide quantitative data, in absolute terms, for emissions and energy consumption, water and materials, during the reporting period, and data to make comparisons with the previous year.

It is preferable that these figures are expressed in physical units rather than in monetary terms. Furthermore, for a better understanding of their relative importance and their evolution, figures in monetary terms could be compared with items shown on the balance sheet or profit and loss;

e) If the company issues a separate environmental report containing quantitative or qualitative environmental information more detailed or additional, it is also worth mentioning that report.

If the report contains the information specified in paragraph (d) it is possible to give a brief description of the issue and an indication that additional information included in the environmental report. The information provided in a separate environmental report must be consistent with any related information in the report and annual accounts of the company.

If the environmental report has been subject to external audit, it should be mentioned in the annual report. Indeed, it is desirable to indicate to users of the annual report if the environmental report contains information or not objective and externally verifiable data

\section{References}

1. ACCA (2004), «Towards transparency: progress on global sustainability reporting», Corporate Register.com, London, $64 \mathrm{p}$.

2. Adams et Kuasirikm. (2000) «A comparative analysis of corporate reporting on ethical issues by UK and German chemical and pharmaceutical companies », European Accounting Review, vol. 9, pp. 53-79.

3. Allouche J., F., Huault, I. (2004). « Information des actionnaires et Rapports RSE 》 Communication Journée du GreGor/IAE de Paris - 26.11.03, Gouvernance et Développement Durable. 
4. Andre P. (1999), « L'évaluation des impacts sur l'environnement - Processus acteurs et pratiques ». Canada: Presses internationales polytechniques, p 416.

5. Bartolomeo, M. (2000) «Environmental management accounting in Europe: current practice and future potential», European Accounting Review, Vol. 9, n ${ }^{\circ}$, pp. 31-53.

6. Beauchamp A. (1993), «Introduction à l'éthique de l'environnement», Collection Interpellation, Editions Pauline.

7. Boritz, J.E (1990), «L'information sur le risque et l'incertitude » Toronto : ICCA.

8. Canadian Institute of Chartered Accountants. (1994) «Reporting on environmental performance», CICA. Toronto.

9. Capron M. et Quairel-Lanoizelée F. (2004), « Mythes et Réalités de l'Entreprise Responsable», Revue de l'Organisation Responsable, $n^{\circ} 3$, pp 18-27, Paris.

10. Capron, M. et Gray, R. (2000) « Experimenting with assessing corporate social responsibility in France: an exploratory note on an initiative by social economy firms », European Accounting Review, Vol. 9, nº 1, pp. 99-111.

11. Capron, M. et Quairel-Lanoizelee, F. (2007), «La responsabilité sociale d'entreprise », Coll. Repères, La découverte édition.

12. Carroll A. (1979), «Three-dimensional conceptual model of corporate social performance», Academy of Management Review, $\mathrm{n}^{\circ} 4$.

13. Cormier, d. et al. (2001) "Environmental reporting management: an international perspective", WP, ${ }^{\circ}$ 04-2001.

14. Delphine, G.-A. (2008), « La perception du dirigeant de PME de sa responsabilité sociale : une approche par la cartographie cognitive», Thèse présentée à la Faculté des sciences économiques et sociales, université de fribourg, Suisse.
15. DYE R.A. (1985), "Disclosure of non proprietary information", Journal of Accounting Research, 23, spring, pp. 123145.

16. Ernult. J., Ashta. A., (2007), «Développement durable, responsabilité sociale, théorie des parties prenantes: Evolution et perspectives » Cahier du CEREN 21.

17. Fortin J. (1995), «Enjeux comptables de la question environnementale », Accounting Ethics Journal. Montréal, Quebec, H3T 1V6.

18. Gray, R. (1990), «The greening of Accountancy: The profession after peace», The Chartered Association of Certified Accounting, Research Report.

19. Guthrie, J. et Parker, L.D. (1990) « Corporate social disclosure practice : a comparative international analysis ", Advances in Public Interest Accounting, Vol. 3, n 1, pp. 159-175.

20. GRAY R. (2002), "The social accounting project and Accounting Organizations and Society Privileging engagement, imaginings, new accountings and pragmatism over critique?", Accounting, Organization and society, $\mathrm{n}^{\circ} 27$, pp. 687708.

21. Hawkshaw, A. (1991), "Qui veut peut », CA magazine, mars.

22. ICCA (2007b), «La nécessité de l'information sur le développement durable de plus en plus reconnue», http://www.camagazine.com/index.cfm/ci id/36916/la id/2. Consulté le 9/12/2010.

23. ICCA (2007c), "Guide de l'ICCA sur l'adoption des IFRS au Canada », Toronto, $p$ 102.

24. ICCA. (1992), «La vérification environnementale et la profession Comptable», Rapport de recherche.

25. ICCA. (1980), «L'information financière publiée par les sociétés : Evaluation future », étude de recherche. 
26. ICCA. (1993b), «Coûts et Passifs Environnementaux: Comptabilisation et Communication de l'information Financière », Toronto ICCA,

27. ICCA. (1994), « Note d'orientation sur la vérification des états financiers sur lesquels des éléments environnementaux a une incidence », janvier.

28. Jonas H. (1990), «le Principe de Responsabilité » Traduit par Greisch, Paris, le Cerf.

29. Mathews, M. R. (1993), «Socially responsible accounting», London: Chapman Hall.

30. Mikol, A. (2005), «La pratique européenne des informations environnementales en 2004 », RFC, n³73, janvier, p. 19.

31. Mohamed M'HAMDI et Sabah TRID, (2009), «La responsabilité sociale de l'entreprise au Maroc: une étude empirique auprès des petites et moyennes entreprises de la région de Fès Boulemane », 11eme journées scientifiques de réseaux Entrepreneuriat AUF.

32. Moneva et Llena. (2000) «Environmental disclosures in the annual reports of large companies in Spain ", European Accounting Review. Vol. 9, pp. 729

33. Moussé J. (1997) «Ethique et profit aujourd'hui», Revue française de gestion, $\mathrm{n}^{\circ} 112$, pp, 52-58.

34. OXIBAR B. (2003), «La diffusion d'information sociétale dans les rapports annuels et les sites Internet des entreprises françaises», Thèse de doctorat en Sciences de Gestion, Université de Paris 9 Dauphine, Paris.

\section{O'DONOVAN}

G.

(2002),

"Environmental disclosures in the annual report: Extending the applicability and predictive power of legitimacy theory, Accounting, Auditing and Accountability Journal, vol.15, n³, pp.344-371
36. Peskin, H.M. (1991), «Alternative Environnemental and resource Accounting Approaches », dans R. Constanza, ed., Ecological Economics: The Science and Management of Sustainability, NY : Colombia University Press.

37. Rogers, C.G. (2005), «Financial reporting of environmental liabilities and risks after Sarbanes-Oxley», Wiley publications, Norwalk, ISBN 0-471-71743$0, \mathrm{p} 378$.

38. Rubinstein M. (2006), « Le développement de la responsabilité sociale de l'entreprise : une analyse en termes d'isomorphisme institutionnel ", Revue d'Economie Industrielle, 113, pp, 83-105.

39. Salomone et Galluccio. (2001) « Environmental issues and financial reporting trends in the chemical and oil and gaz industries », Working paper, $n^{\circ} 32$.

40. Schaltegger, S. and Burrit, R. (2000), "Contemporary environmental accounting. Issues, concepts and practice», Sheffield, Greenleaf Publishing 2000, ISBN 1-87471934-9, p, 462.

41. Skinner, R.S. (1987), «Accounting Standards in Evolution» Toronto: Holt, Rinehart and Winston.

42. Turner, K. R., Pearce, W. D. (2003), «Economia ambientale», Bologna, Il Mulino.

43. Yusoff, H., Lehman, G. (2005), «International differences on corporate environmental disclosure practices: a comparaison between Malaysia and Australia», University of South Australia, p 28. 